Варвара Б. ХЛЕБНИКОВА* Московски државни универзитет Ломоносов
Оригинални научни рад Примљен: 04. 11. 2016. Прихваћен: 10. 02. 2017.

\title{
ПУТОПИСНЕ И НОВИНАРСКЕ БЕЛЕШКЕ П. А. РОВИНСКОГ О СРБИЈИ
}

\begin{abstract}
У овом реферату ће бити речи о путописним есејима познатог руског слависте Павла Аполоновича Ровинског, који је у периоду од 1868. до 1869. године као новинар радио у Кнежевини Србији. Чланци Ровинског, објављени у познатим руским новинама и часописима, испуњени су драгоценом историјском и етнографском информацијом о животу српског народа у другој половини XIX века. Ови подаци могу бити веома интересантни српским стручњацима.

Кључне речи: Павле Ровински, Кнежевина Србија, путописни есеји, историја и етнографија српског народа.
\end{abstract}

Павле Аполонович Ровински (1831-1916) је оставио значајан траг у руској славистици. Десетине писама, стотине научних чланака и вишетомна монографија о Црној Гори постали су својеврсни споменик његовом вишегодишњем научноистраживачком раду на изучавању Јужних Словена. Више од четврт века П. А. Ровински проводи на Балкану. Биографија овог слависте била би добар сиже за неки авантуристички роман. Сиромашни племић из Саратовске губерније, студент Казанског универзитета, даљи рођак познатог књижевног критичара и револуционара Николаја Гавриловича Чернишевског, Ровински започиње свој друштвени рад активним учешћем у револуционарној организацији „Земља и слобода”. Након њеног уништења, почиње да се бави научним радом и новинарством. Много путује по свету, а шездесетих година XIX века проучава историју и јавни живот Чеха у Аустроугарској и Словена на Балканском полуострву. Затим одлази у Сибир где проводи истраживања у области историје, етнографије и географије. Стигао је до Монголије и написао низ сјајних есеја о тим, за Европљане скоро непознатим крајевима. Након тога, са ентузијазмом почиње да се бави педагошком делатношћу, и постаје директор специјалне образовне установе - земљорадничке 
колоније за малолетне делинквенте. Његове иноваторске методе васпитавања проблематичне омладине добиле су највише оцене од савременика, као на пример од Ф. М. Достојевског. У другој половини седамдесетих година XIX века, када је на Балкану завладала политичка криза, П. А. Ровински није могао остати по страни. У јулу 1878. године, као дописник популарних новина Ново време, прво путује у Аустрију, затим у Србију и најзад стиже до Босне и Херцеговине, редовно извештавајући руске читаоце о томе како се одвија аустроугарска окупација словенских крајева. Руски слависта је у Сарајеву провео пет месеци, где се налазио под непрестаном контролом аустријске полиције. На крају су аустријске власти без дугих објашњења протерале новинара са својих нових територија. Био је депортован на границу са Црном Гором. Тамо учествује у последњим војним операцијама Црногорске народне војске у борби против Турака. Након тога, на дуже време остаје у Кнежевини, постаје њен највернији пријатељ, помоћник и „хроничар”. Једна од улица старог Цетиња данас носи име П. А. Ровинског.

Желели бисмо да у овом реферату размотримо садржај и уметничку вредност радова које је П. А. Ровински написао о Србији током и након путовања 1868-1869. године. Надамо се да ћемо привући пажњу стручњака-филолога, који би можда сматрали вредним превести радове овог слависте на српски језик и тако упознали читалачку публику с оним што је пре више од сто година било написано о Србији. Године 1868. Ровински стиже у Кнежевину као дописник листа Петербуршке ведомости (СПб ведомости). Уредник тих руских либералних новина В. Ф. Корш је био убеђен да ће на Балкану сваког тренутка избити нови рат са Турцима. Зато је редакција сматрала да ће јој ускоро затребати стручни сарадник. Тако је слависта добио акредитацију у Београду и његов службени пут је трајао од фебруара 1868. до јесени 1869. године. Корш је погрешио само у једном - није се догодила спољашња, већ унутрашња катаклизма, позната као „топчидерска катастрофа” (убиство кнеза Михаила Обреновића, које су извршиле присталице Карађорђевића 29. маја 1868. године у Топчидерском парку, надомак Београда).

П. А. Ровински је 12. (24) марта 1868. године, објавио свој први есеј „Од Петрограда до Београда". ${ }^{1}$ До октобра 1868 . године у Петербуриким ведомостима је било објављено преко двадесет бележака и писама о политичком животу Кнежевине. Током 1869. године новине штампају још осам чланака П. А. Ровинског. Али, слависта је био врло незадовољан већином публикација. У писму пријатељу и колеги А. Н. Пипину пише да редакција самовољно скраћује његове текстове и много тога не штампа. На пример, у новембру 1868. године Ровински се жали Пипину да новине нису у потпуности објавиле репортажу о суђењу убицама кнеза Михајла, и моли га да му помогне да објави чланак о Омладини. ${ }^{2}$ На крају је ипак морао да прекине сарадњу са листом. То је Ровински објаснио у писму Пипину овако: „, Хтео бих да будем уверен да, осим зараде, доносим још неку корист људском

\footnotetext{
${ }^{1}$ СПб ведомости. 23. марта 1868. по старом календару.

${ }^{2}$ Отдел рукописей Российской национальной библиотеки СПб (даље ОР РНБ). Фонд 621. Дело 722. Л.7.
} 
роду. Свако ко има бар мало самопоштовања, гледа тако на свој труд, значи, и ја имам право да своје дописе сматрам корисним за друштво". ${ }^{3}$ Научник је покушао да сарађује са другим либералним новинама Глас, чији је издавач био А. А. Крајевски, али поново без успеха. У писму, послатом 18. јануара 1869. године, Ровински ступа у полемику са Крајевским: „Ви желите да добијате краће извештаје, али чешће”. Сматрајући да такав приступ није правилан, слависта је инсистирао на томе да је пуно важније анализирати ток догађаја и упознавати читаоце са чињеницама и околностима које дају материјал за дубока размишљања: „Оне могу имати огроман значај. По мом мишљењу, задатак дописника се састоји у томе да запажа и изучава такве појаве”. Слависта је сматрао да новинар не сме да жури и да је дужан да проверава информацију. Јурњава за сажетошћу само означава „жртвовање суштине". ${ }^{4}$ Нажалост, научнику није пошло за руком да убеди издаваче да је у праву, он прекида сарадњу са новинама, и посвећује се научном раду и просветитељству. С тим циљем је 1868-69. године П. А. Ровински радио у Музеју Београда, путовао и обишао пешице оживљена и забачена места Кнежевине, активно се упознавао са људима из разних социјалних и етничких група. У писму свом учитељу, професору Казанског универзитета В. И. Григоровичу, Ровински саопштава да изучава „свакидашњицу Словена кроз призму њиховог савременог живота, њихове историје и књижевности, преко рукописа и других споменика старине." есеја о Србији, написаних и објављених у солидним руским друштвено-политичким и књижевним часописима (в. Ровински 1868, 1870а, 1870б, 1875a, 18756, 1876). За разлику од новинске кореспонденције, ови текстови су до нас стигли онакви како их је сам аутор написао: самобитни, нису исправљени руком уредника нити скраћени ради уредничког одбора, нису „очишћени” из политичких разлога. Чланци не само што су препуни информације која је новинарима изгледала небитном него су и емоционални, лирски надахнути и са доста поређења. Мешавина научног, публицистичког и књижевног стила, постала је главна вредност радова овог руског путописца.

Ако генерализујемо садржај путописних есеја, може се рећи да основно место у њима заузима неколико тема. Прво, то је природа Србије, шуме, планине, реке које су приказане научнички детаљно и у исто време са правим одушевљењем, понекад чак са усхићењем. Узмимо, на пример, опис реке Саве у пролеће:

Ту и тамо је земља, тек што се појавила испод воде, већ успела да се покрије јарким свежим зеленилом или сасвим, као снегом, прекрије белом мишјакињом [...] Над нама круже бели галебови; а обалом безбрижно тумара чапља, гостећи се у плићаку разним воденим посластицама [...]. Какав је само биљни свет на адама?! Оне су скроз зарасле у храст, чија је тамна крошња, као увојцима, украшена светлим зеленилом дивљег грожђа, а његова унутрашњост, на једно два хвата висине, окупана у јарко-пурпурну боју дивље руже, која га је, пробијајући се ка светлости кроз шикару његових грана и тамног лишћа,

\footnotetext{
${ }^{3}$ ОР РНБ. Ф.621. Д.722. Л.5, превод аутора.

${ }^{4}$ ОР РНБ. Ф.391. Д. 666. Л.1, превод аутора.

${ }^{5}$ ОР РНБ. Ф. Григоровича. Картон 4. Д.117. Л.4, превод аутора.
} 
обасула својим цветовима. На ливади је трава више колена, и са њеног разнобојног тепиха се с времена на време шири пријатан мирис (Ровински 1875a: 19, превод аутора).

Тако бисмо желели да тај, пробуђени после зиме и процветали пејзаж, упоредимо са Србијом која се препорађала након неколико векова угњетавања. Још један пример, како је природу Кнежевине видео видео П. А. Ровински:

Планине у Србији су углавном покривене шумом и ретко где су то голе стене [...] ретко где прелазе у предео под црногорицом. У шумама Србије је најраспрострањенији храст, а у брдима свуда расте претежно једна врста храста, који се на српском зове „цер” (quercus cerris). То је једна од најлепших врста европског храста: има равно стабло, које постепено достиже до танког, шиљастог врха; гране су му танке, дугачке; кора му је сва у дубоким уздужним пукотинама кроз које се назире црвенкасто тело; лист му је мали и не са толико дубоким изрезима; жирови су му далеко крупнији него код других врста, и расту у гомили, до пет комада у једном гнезду које је споља длакаво и бодљикаво; цер садржи много смоле, па га зато и сматрају добрим грађевинским и одличним огревним материјалом; а његовим жировима, пре свега, тове свиње, које су један од главних извора богатства Србије (Ровински 1875б: 700, превод аутора).

Задивљујуће је како је аутор у једној реченици могао да да̂ читаоцу тако много информација. То су и карактеристике српског пејзажа, и подаци о преовлађујућим врстама дрвећа, и приповедање о томе каква је улога дрвета у привреди Срба. Притом је натуралистички опис храстова, неприметно за читаоца, прелазио у поетски, пун дивљења савршенству и лепоти дрвета које тако улепшава људски живот. Описи пејзажа у есејима П. А. Ровинског представљали су успешан књижевни поступак. Они су оживели научни текст, приближили га уметничком стилу, и пренели читаоца у расположење и емотивно стање самог аутора. Није сваком путнику који је водио путописне белешке полазило за руком да у својим делима тако префињено уједини научна и лирска размишљања.

Друга тема, о којој је П. А. Ровински детаљно писао у својим чланцима, јесу српски градови и села. Нису то само места која би, пошто их је већ посетио, савестан путописац требало да опише са историјске и етнографске тачке гледишта. Шабац, Лозница, Ужице, Пожега и други градићи и насеља, на страницама есеја живе пуним животом, расту и модернизују се, попримају европски изглед, али притом не губе свој древни антички и османлијски колорит. Централно место у есејима је посвећено Београду - граду са својим карактером, посебним ритмом живота, усмереном у будућност, граду који се динамично развија и постаје све лепши из дана у дан. Слависта је саопштавао читаоцима да је статистика насељавања српске престонице веома оптимистична, да се град брзо гради, зидају се двоспратне и троспратне камене куће, буквално преко ноћи мења свој источњачки изглед ка западњачком. С једне стране, нови Београд је подсећао писца на многе, пријатне и удобне за живот аустроугарске провинцијске градиће. С друге стране, научник је истицао да политички и административни центар Кнежевине није изгубио свој непоновљив национални колорит. Стари турски квартови остали су верни вековном османлијском начину живота, дочекујући путника „лавиринтом 
уских вијугавих улица на које излазе само високе ограде". Источњачке тезге и занатске радње, по мишљењу П. А. Ровинског, изграђене су исто онако, као што су их описивали путописци још у XVII веку (Ровински 1870a: 548-550, превод аутора). Насупрот њима, нови српски делови града јако су се истицали тежњом за удобношћу и комфором. Упоредо са пољем покрај Калемегданске тврђаве, које је зарасло у траву, појавио се тек засађени парк и недавно изграђене фонтане. Цркве и хотели, улице са кестенима, тополама и багремима - „све гледа весело и широко”, све изазива симпатију и изгледа срдачно. „Мало је градова у Европи, који су у стању да одмах оставе такав пријатан утисак, као Београд" - тврдио је П. А. Ровински (Исто: 546).

Описујући изглед српских градова и села, научник је стално истицао необичан сплет три моћна цивилизацијска утицаја. На сваком кораку је било видљиво колико је много на Балкану остало тога од античког Рима. Посебан утисак на слависту је оставило то што се римско наслеђе непрестано откривало у изнова грађеном Београду:

Као у Херкулануму и Помпеји под гомилом пепела и лаве откривају се куће са свим покућством [...] тако и у Београду, под слојем глине и шљунка сваки час се појављују грађевине и различити предмети који сведоче о томе да је некада овде живео један сасвим други народ и да је овде била сасвим друга култура (Исто: 555).

Често су се, по читавој Србији, остаци древних римских рушевина користили као грађевински материјал који је ,тако добар, да сав иде на нове зграде”. Антика је била снажан културно-историјски темељ на коме је стајала нова Србија. Други историјски слој, који је определио архитектурну посебност Кнежевине је османлијска прошлост. Џамије и тврђаве за војне гарнизоне, источњачке стамбене четврти и турски базари остали су органски део српских насеља, који им је придавао нијансу оријенталног колорита. Без чари османлијске прошлости српски градови би изгледали као обична европска провинција. На те остатке старине су у другој половини XIX века чврсто приањали слојеви савремене европске индустријске цивилизације, чинећи живот човека угодним, комфорним и стабилним. Фабрике које су се градиле, пилане, воденице, савремени дућани, административна здања, као да су истицали да је Кнежевина од сада па заувек везана за индустријски развијену модерну Европу. Строги историзам у споју са уметничким детаљима и лирским додацима, омогућили су П. А. Ровинском да са фотографском прецизношћу дочара руском читаоцу самобитност и јединственост Кнежевине Србије у ХІХ веку.

Лајтмотив, основна сижејна линија путописних есеја за слависту је било познанство са српским народом. Аутор је искрено писао о земљи коју је тежио да дубоко изучи и схвати, не допуштајући себи да даје лажну слику идеалног словенског живота, пуну празних комплимената: „Мера којом оцењујем српски народ је иста она коју примењујем према Русији и према сваком другом народу [...]" (Исто: 162). П. А. Ровински је био убеђен да сваки народ има своје добре и лоше стране, и да Срби заслужују да чују истину о себи. Зато су људи и друштвени типови, са којима се научник упознао у Кне- 
жевини, били за њега најдрагоценије откриће. Ти су људи живели у посебној друштвено-политичкој и духовној атмосфери. С једне стране, они су се недавно ослободили страног угњетавања и градили своју националну државу, постизали одређене успехе и правили грешке, разочаравали се у своје вође. С друге стране, суседство са експанзионистичком Аустроугарском и очување власти Отоманског царства на територији Старе Србије, Босне и Херцеговине чинили су живот српског народа нервозним, напрегнутим, бременитим конфликтима и опасношћу избијања новог рата. Све је то, по мишљењу Ровинског, одвлачило српски народ од мирнодопских занимања, претварало свакодневницу у нешто крхко, миран живот је био несигуран. У ваздуху је лебдела ратна опасност, претварајући младу државу у „полувојни логор”.

Проучавање карактера српског народа, расположења и очекивања, начина размишљања појединих његових представника, за П. А. Ровинског су били основни циљ путовања по Кнежевини. Буквално од првог тренутка свог службеног пута, он је почео да „сортира” своја запажања. Отворену симпатију аутор је испољавао према „фабричким [радницима] и занатлијама разних врста”: „Милина је била гледати на тај народ, свеж, физички снажан, здрав и ведрог духа, вредан и предузимљив" (Ровински 1868: 366, превод аутора). Млади, дотерани младићи „који умеју да се држе достојанствено”, подсећали су писца на руске студенте. Знао је он да су ти млади момци, пре него што почну да раде у фабрици, похађали високе техничке школе, међутим, нису могли да заврше школовање због недостатка новца. Први утисци нису преварили путописца. Дошавши у Београд, и касније кренувши на пут по Кнежевини, научник је наставио да посматра обичне трудбенике, оне које обично европски путник или није ни примећивао или их је кудио због неспретности. На пример, обратио је пажњу на београдске носаче који су нудили своје услуге, али „да вам се намећу силом, није био њихов обичај”. Ти су људи за тежак рад добијали мизерну надокнаду, која је једва могла да их прехрани. Још више га је погодила пракса која је владала у београдским хотелима, када женској послузи власници често нису сматрали за сходно да дају плату, користећи се бесплатним радом тих несрећних жена. Заправо, П. А. Ровински је приметио да се у Београду сфера услуга очито разликовала од онога на шта су навикли људи из Западне Европе. Демократизам и једноставност у свакодневном животу изгледали су као „непредусретљивост”, и то се „веома није допадало људима који су навикли на европски буржоаско-господски начин живота" (Ровински 1870а: 531, превод аутора).

Оштро око научника као да је истрзало из гомиле час једно, час друго лице. П. А. Ровинском су били интересантни сви: и меланхолични београдски кочијаши, који су путописца подсетили на становнике са југа руске империје, и Срби из Баната и граничар, с којим је имао прилику да се сретне на палуби путничког брода, и аустријски поштар, и турске дућанџије које су израђивале и одмах продавале своје производе. Радни народ Србије, без обзира на имовинско стање и националност, изазивао је код руског новинара саосећање и поштовање. Према његовом мишљењу, сав занатлијски живот Београда је „на видело”, и то га разликује од „делатности чиновника, нови- 
нара и књижевника уопште; недокучивом тајном је обавијена и делатност српског државника и дипломате" (Исто: 551). Једноставан и искрен начин живота, поштен рад, осећање људског достојанства и умеће да стоички подноси разне недаће - то је привлачило научника-демократу код српског народа.

Током путовања земљом П. А. Ровински је стално испољавао исту жељу за дружењем и разумевањем проблема сељака, пастира, учитеља, војника, трговаца, неимара. За сваког је налазио умесне и сликовите речи. Српске трговце је слависта назвао ,занимљивим, вештим и марљивим људима” (Ровински 1870б: 168, превод аутора). Српске учитеље је похвалио за природну сналажљивост, и укорио за мањак научних знања. Свештеници су га зачудили својим активним учешћем у разним друштвеним секцијама и интересовањем за политику: „Тако је мало у тим људима аскетског и толико активно учествују у свему овоземаљском, да се никако не могу сматрати било чиме посебним од народа и народног живота." (Ровински 1875б: 702, превод аутора). Са неколико добро смишљених реченица, јарким детаљима, етнографски подробним описима амбијента у домовима, покућства и предмета за свакодневну употребу, одеће, аутор живописно слика необични живот земље која се налазила у прелазном стању. Наново су се градили градови, оснивале националне државне институције, Кнежевина је тражила своје место у међународним односима. И то је условљавало начин живота сваког појединца, утичући чак на његов изглед. „Одећа привлачи пажњу мешавином општеевропског и националног. Један је у црном капуту и са црвеним фесом на глави, други, напротив, сав у српској ношњи, а на глави - шешир", забележио је Ровински (Ровински 1875a: 20, превод аутора). Срби су, као млад државотворни народ, били интересантни за научника који је тежио да одгонетне механизме друштвеног живота и схвати процесе модернизације.

Јавни живот Кнежевине, политичка збивања и потреси разоткривали су путописцу српски национални карактер. Веома га је збунило прво познанство са кнежевском бирократијом. Детаљан претрес на царини, очигледно неправична и неумесна ситничарења, строга пасошка контрола - све је то изазвало недоумицу. Такође га је запањио број жандара по глави становника: „На сваких 50 људи српска влада има једног жандара” (Ровински 1870а: 531, превод аутора). Касније је слависти та тежња владе да држи читаво друштво под тоталним надзором постајала све очигледнија. У престоници се строги полицијски режим још и могао оправдати тиме да постоји политичка опозиција, да се против клана Обреновића плету завере и интриге. Али у забаченим насељима, куда се завукао научник у тражењу материјала за свој рад, полицијска ревност је изгледала апсурдно и смешно. У околини села Крупањ на Дрини П. А. Ровински је пао под сумњу локалног пандура. Чиновник је од путника затражио пасош, али ништа није могао да разуме, пошто није знао да чита. Допремили су га у најближу караулу, где се испоставило да је начелник страже (,буљубаша”) такође био неписмен. Истина, „старији и довољно разуман господин” је брзо схватио да руски дописник не представља опасност и пустио га је на све четири стране света. Ускоро се у Љубовији ситуација поновила. Опет су научника ухапсили опрезни војници и привели 
га поднареднику, који је знао да чита и пише, али није разумео руски текст у пасошу. Ревносни војник је послао странца официру вишем по чину, а тај je, за несрећу, био заузет картањем. Држали су Ровинског под стражом до следећег јутра, док се, после непроспаване ноћи, није наспавао строги али неажурни представник власти. Јасно је да су такви контакти са званичним лицима, били супротни пријатељској пажњи и гостопримству, које су на сваком кораку П. А. Ровинском пружали Срби, и то не они који су били на власти, већ они који су зарађивали за живот својим радом.

Веома је противречан утисак на путописца оставило познанство са особеностима политичке борбе у Кнежевини. Слависта је стигао у Србију у тренутку када је незадовољство владавином Обреновића достигло кулминацију. Атмосферу која је владала у друштву Ровински је описивао овако:

Кнез [...] не верује народу, крши његова права уз помоћ скупштине, и, окруживши се чиновницима аустријског кова, повлачи се у свој конак (дворац), и остаје глув и слеп за све што се дешава у земљи. Сва пажња је усредсређена на полицију и војску. Читава Србија се претворила у огромну полицијску управу; некакав свеопшти терет, тежак осећај је носио у себи свако ко се тада налазио у Београду и ко се кретао у различитим круговима (Ровински 1875a: 13-14, превод аутора).

Ипак, убиство кнеза Михаила у мају 1868. године није умањило напетост у земљи. Присталице Милана, који је ступио на престо, сурово су се обрачунавале са противницима, спроводила су се хапшења, политички процеси, а јавност је преплашено ћутала или лицемерно демонстрирала лојалност и приврженост новој администрацији. П. А. Ровинског је непријатно изненадио један познаник, који је носио „црни повез на руци”, „нарицао и јадиковао”, мада је неколико дана пре убиства кнеза Михаила оштро критиковао власт (Ровински 1870б: 155, превод аутора). Таква политичка мимикрија и лицемерје су изазивали одвратност код руског научника, који је иза себе имао веома бурну револуционарну прошлост. На част П. А. Ровинском треба истаћи да је он додељивао улози политике у животу народа исто толико места колико је она заслуживала, никада не стављајући знак једнакости између политиканата и обичних људи, који су поштено радили и изграђивали своју земљу.

Иронија, као уметнички метод, помогла је писцу да ублажи запажања и примедбе које су биле критичког карактера. Увидевши неискреност оних који су лицемерно јадиковали за убијеним кнезом, научник се посвећује ширем филозофском питању. Шта је за просечног становника Србије приоритет у животу, о чему машта, шта жели да постигне? Пажљиво размотривши Србе, П. А. Ровински је духовито описао њихову, на први поглед, романтичну, али у суштини, прагматичну природу.

Он [Србин] често воли да поразговара о лепоти природе, да се одушевљава звезданим небом и удуби у недокучиве тајне свемира, притом се препуштајући најмистичнијим тумачењима, да се диви нежном цвету, да опева дубока осећања која пружа породични живот, да се диви идеалној лепоти женског портрета на фотографији итд. Али у исто време, убеђен сам, увек ће пре дати предност доброј заради него свим другим циљевима овог света, све природне лепоте је спреман да да за масну сарму у виновом или у листу од ку- 
пуса, или за младу јагњетину са ражња, шпиковану белим луком и и зачињену паприком, и никако није савршенство оно што га привлачи у женској лепоти (Ровински 1870б: 137, превод аутора).

Моралисти, убеђени у сопствену непогрешивост, дуго би певали жалопојке о примитивности српског народа. П. А. Ровински је поступио другачије. Да, многи Срби маштају о личном благостању и успешној чиновничкој каријери. Да, Србима је својствена нека самоувереност, самозаваравање, преувеличавање својих достигнућа. Да, они „не воле да се у било шта удубљују, воле да купе кајмак”, повремено бивају сувише тврдоглави. Али који је народ савршен, где се на земаљској кугли може наћи идеалан човек? Научник је одмах упоредио Србе са Русима, како би напоменуо читаоцу да се према свим народима треба односити са подједнаким поштовањем:

Немају Срби ту песничку безбрижност, некакву апатију и немар, који карактеришу руског човека и, без обзира на полувојнички начин живота, на то што нису навикли и не умеју да се добро организују, они спречавају многе невоље својом опрезношћу, сталном бригом и трезвеношћу, управо тим особинама, које нама [Русима] највише недостају (Ровински 1870а: 553, превод аутора).

На тај начин, упознавши се ближе са српским народом, осетивши према њему дубоку симпатију, али га нимало не идеализујући, П. А. Ровински је као научник подробно и изражајно, занимљиво и на уметнички начин испричао руској читалачкој публици све што је и видео и изучио. У Русији су његови радови били добро прихваћени. Али, вероватно, само Срби могу на прави начин да оцене дубину и објективност закључака до којих је дошао руски научник након путовања по Кнежевини Србији.

\section{ЛИТЕРАТУРА}

Хлебникова 1987: В. Б. Хлебникова. Павел Аполлонович Ровинский в Черногории // Славяноведение. № 2, 25-31.

Хлебникова 2006: В. Б. Хлебникова „Русский черногорец” Павел Ровинский // Родина. № 4, 75-77.

\section{ИЗВОРИ}

ОР РНБ. Ф. Григоровича. Картон 4. Д. 117

ОР РНБ. Ф. 391. Д. 666

ОР РНБ, Ф. 621. Д. 722

Ровински 1868: П. А. Ровинский, Два месяца в Сербии (Из путевых воспоминаний), у: $B E$, кн. 11, ноябрь, 364-386.

Ровински 1870a: П. А. Ровинский, Белград. Его устройство и общественная жизнь. Из записок путешественника, у: BE, кн. 4, апрель. 530-579; 
Ровински 1870б: П. А. Ровинский, Белград. Его устройство и общественная жизнь. Из записок путешественника, у: BE, кн. 5, май, 132-188.

Ровински 1875a: П. А. Ровинский, Воспоминания из путешествия по Сербии в 1867 году, у: $B E$, кн.11, ноябрь, 5-34.

Ровински 1875б: П. А. Ровинский, Воспоминания из путешествия по Сербии в 1867 году, у: $B E$, кн. 12, декабрь, 699-725.

Ровински 1876: П. А. Ровинский, Сербская Морава. Воспоминания из путешествия по Сербии в 1867 году, у: $B E$, кн. 4, апрель, 517-558.

СПб ведомости 23.3.1868.

Русские о Сербии и сербах. T.I: Письма, статьи, мемуары. Сост., вступ. ст., закл. А. Л. Шемякина. Комм. А. А. Силкина, А. Л. Шемякина. СПб, 2006, 684.

Русские о Сербии и сербах. Т.ІІ: архивные свидетельства. Сост. А.Л. Шемякин. Комм. А.А. Силкина, А. Л. Шемякина. М. 2014, 631.

Varvara B. Hlebnikova

P.A. ROVINSKY'S TRAVEL AND JOURNALISTIC NOTES ON SERBIA

(Summary)

The paper discusses the travel essays of the renowned Russian Slavicist Pavel Apolonovich Rovinsky, who worked as a journalist in the Principality of Serbia in 1868 and 1869. Rovinsky's articles, published in respectable Russian journals and magazines, are supplied with valuable historical and ethnographic information on the life of the Serbian people in the second half of the 19th century. This information could be of great interest to Serbian scholars. 